\title{
Study on Knowledge and Practice of Periconceptional Intake of Folic Acid among Antenatal Mothers at Saveetha Medical College Hospital, Tamil Nadu
}

\author{
Shanthi Ethirajan ${ }^{1}$, Mangala Lakshmi Pritem ${ }^{2}$
}

\begin{abstract}
Background: Neural tube defects (NTDs) are one of the common congenital malformations. Neural tube defects are preventable with folic acid (FA) supplementation periconceptionally. Knowledge about FA and its periconceptional intake among women of reproductive age, pregnant women, and healthcare providers is important for timely supplementation, thereby preventing NTDs.

Aim and objective: To assess the knowledge about FA and its benefits and their actual intake of FA periconceptionally among pregnant women at Saveetha Medical College and Hospital.

Study design: A cross-sectional descriptive study was conducted at Saveetha Medical College and Hospital in the year 2017.

Materials and methods: Two hundred pregnant women attending Antenatal Outpatient Department willing to participate in the study were interviewed with a structured questionnaire and responses were collected and analyzed.

Results: Among 200 pregnant women, 153 (76.5\%) women had heard about FA and mostly from healthcare providers (94.7\%). Sixty-one women (30.5\%) and nine women (4.5\%) were aware of the benefits of FA in neural development and anemia prevention, respectively. Nine (4.5\%) were able to mention a diet rich in FA and $15(7.5 \%)$ women knew the dose of FA. Only 32 women (16\%) took FA periconceptionally, whereas 150 women (75\%) took FA only after the diagnosis of pregnancy. Among them, 164 women took the tablets regularly. Eighteen women (9\%) did not take FA during pregnancy. Out of 131 women (65.5\%) who had planned pregnancy, only 48 women (36\%) had taken periconceptional FA. Conclusion: Awareness about FA and its importance of periconceptional intake is low among women in this population. The practice of periconceptional intake of FA is less which may be due to a lack of knowledge about the benefits of FA. Health education, awareness programs, planned pregnancy, and preiconceptional counseling can help in optimizing the periconceptional FA intake.

Keywords: Folic acid, Nutritional supplements in pregnancy, Periconceptional period, Planned pregnancy, Prevention of neural tube defects. International Journal of Infertility and Fetal Medicine (2020): 10.5005/jp-journals-10016-1212
\end{abstract}

\section{INTRODUCTION}

Folate is an essential water-soluble vitamin B. As it cannot be synthesized within the body, it has to be taken into the diet. ${ }^{1}$ Folate is the natural form available in green leafy vegetables, meat, dairy products, and egg. Folic acid (FA) is the synthetic form of folate used for the fortification of food and medication. It is essential for growth and is a component of various enzymes, DNA, RNA, and hemoglobin synthesis. ${ }^{2-5}$ Its supplementation is important during pregnancy as the demand is more. Its deficiency causes many congenital malformations specifically neural tube defects (NTDs) and megaloblastic anemia. Open neural tubes normally close between the 21st and 29th day of conception. ${ }^{6,7}$ When this closure does not occur, it results in open NTDs ranging from lethal anencephaly to less severe spina bifida causing paralysis of lower limbs. Global prevalence is approximately 1 to $5 / 1,000$ live births and the risk of recurrence is $2-3 \% .^{8}$ In India, the prevalence of NTDs is around $1.4 / 1,000 .{ }^{9}$

Many studies have proven that the occurrence of NTDs can be reduced by $75 \%$ by periconceptional intake of FA and also its recurrence in future pregnancies. ${ }^{710-12}$ Periconceptional period is from 1 month before conception until the first 3 months of pregnancy. ${ }^{13} \mathrm{WHO}^{14}$ and Government of India recommends $400 \mu \mathrm{g}$ of FA intake periconceptionally. ${ }^{15}$ Other benefits of FA supplementation include decreased incidence of anemia, low birth weight, intrauterine growth restriction, preterm delivery, and other malformations like cleft lip, congenital heart defects. ${ }^{1,16,17}$
${ }^{1}$ Department of Obstetrics and Gynaecology, Saveetha Medical College and Hospital, Chennai, Tamil Nadu, India

${ }^{2}$ Department of Obstetrics and Gynecology, Saveetha University, Chidambaram, Tamil Nadu, India

Corresponding Author: Mangala Lakshmi Pritem, Department of Obstetrics and Gynecology, Saveetha University, Chidambaram, Tamil Nadu, India, Phone: +91 9047022320, e-mail: mangalakabali@yahoo. com

How to cite this article: Ethirajan S, Pritem ML. Study on Knowledge and Practice of Periconceptional Intake of Folic Acid among Antenatal Mothers at Saveetha Medical College Hospital, Tamil Nadu. Int J Infertil Fetal Med 2020;11(3):57-60.

Source of support: Nil

Conflict of interest: None

Awareness and knowledge among people about FA and its benefits are important for optimizing periconceptional FA intake. Hence, this study was conducted to assess the knowledge among pregnant women about FA and its benefit and their practice of FA intake during their pregnancy.

\section{Materials and Methods}

This study was a cross-sectional descriptive study carried out at Saveetha Medical College and Hospital during the year 2017. 
The study population was the antenatal women attending the Outpatient Department of Obstetrics and Gynaecology. The study group included antenatal women who were given information about the study and was willing to participate in the study after completely understanding the nature of the study. These women were interviewed with a structured questionnaire and responses were recorded. The questionnaire included the demographic profile of the participants like age, education, occupation, and obstetric details. The questionnaire also included whether they have heard of $F A$, the source of information, the benefits of FA, and a diet rich in FA. Their practice of FA was assessed by asking them if they consumed FA before conception and during conception and their regularity of intake. Data collected were analyzed using Microsoft Excel. The categorical variables were presented as frequency and percentages.

\section{Results}

Totally 200 antenatal women were included in the study. The mean age of the study group was 23.5 years with a range from 16 to 38 years. Among the participants, 3 were uneducated (1.5\%), 1 woman had done primary education, 47 women had completed high school (23.5\%), 70 women had completed higher secondary (35\%), and 79 women had studied beyond higher secondary education (39.5\%) (Table 1). The study group included 107 primigravida (53.5\%) and 93 multigravida (46.5\%). The pregnancy was a planned one in 131 pregnant women (65.5\%). In the study group, 153 women had heard of FA (76.5\%) (Table 2). Among them, the source of information was healthcare providers in 145 women (94.7\%), 3 from media (2\%), and 5 from relatives (3.3\%). Regarding the knowledge about the benefits of FA, 61 women knew that it is needed for neural development of the fetus (30.5\%) and 9 women knew that its intake prevents anemia (4.5\%). Nine women knew the source of FA (4.5\%) and 15 participants knew the dose of FA (7.5\%). Regarding their practice of FA consumption, 32 women took periconceptionally (16\%) and 150 women took FA only after the diagnosis of their pregnancy (75\%)

Table 1: Demographic details of the study group

\begin{tabular}{|c|c|c|c|}
\hline S. no. & Detail & Numbers & Percentage \\
\hline \multirow[t]{6}{*}{1} & Age & & \\
\hline & $\leq 20$ & 25 & 12.5 \\
\hline & $21-25$ & 95 & 47.5 \\
\hline & $26-30$ & 61 & 30.5 \\
\hline & $31-35$ & 17 & 8.5 \\
\hline & $>35$ & 2 & 1 \\
\hline \multirow[t]{6}{*}{2} & Education & & \\
\hline & Uneducated & 3 & 1.5 \\
\hline & Primary & 1 & 0.5 \\
\hline & High school & 47 & 23.5 \\
\hline & 12th standard & 70 & 35 \\
\hline & More than 12th standard & 79 & 39.5 \\
\hline \multirow[t]{5}{*}{3} & Gravidity & & \\
\hline & 1 & 107 & 53.5 \\
\hline & 2 & 62 & 31 \\
\hline & 3 & 28 & 14 \\
\hline & 4 & 3 & 1.5 \\
\hline \multirow[t]{3}{*}{4} & Planned pregnancy & & \\
\hline & Yes & 131 & 65.5 \\
\hline & No & 69 & 34.5 \\
\hline
\end{tabular}

(Table 3). All women who had taken FA periconceptionally had planned their pregnancy. Among FA consumers, 164 were regular in intake (90.1\%) while others (18) took FA intermittently (7\%). Eighteen women in the study did not consume FA during pregnancy (9\%). The reasons for irregular intake and not consuming FA were aversion to medications, vomiting, and forgetfulness, though it was unnecessary to take medications. The practice of intake of FA increased as their educational status increased. As the gravidity increased the percentage of women consuming FA decreased.

\section{Discussion}

Folic acid, an essential vitamin $B$, is known to reduce the incidence ${ }^{10,18}$ and recurrence of NTDs ${ }^{11}$ and megaloblastic anemia in pregnancy. Large clinical trials have proven this fact about FA. Though there has been a global increase in the periconceptional use of FA, it is not the same in all countries. Many studies have shown that still, the level continues to be lower in certain populations. ${ }^{6}$ Hence, this study aimed at assessing the knowledge about FA and its benefit and their actual practice of FA intake in this local population.

The findings of our study revealed that $76.5 \%$ of women in this area had heard about FA which is comparable with the study done by Saxena et al. and found to be higher than that reported in a study done in South India. ${ }^{5}$ Though the result seems to be optimistic, it is less when compared to western countries. ${ }^{19,20} 30.5 \%$ of women in our study knew that FA is needed for neural development of the fetus and $4.5 \%$ of women knew that it is needed to prevent anemia. These results are higher when compared to Indian reports by Saxena et al. and a South Indian study. ${ }^{5,17}$ Again the results are lower when compared to the western population. ${ }^{19}$ Further only 4.5 and $7.5 \%$ of women in the study knew about the source and the dose of FA, respectively. Similar to other studies, it was found that

Table 2: Knowledge about folic acid

\begin{tabular}{|c|c|c|c|}
\hline S. no. & Detail & Numbers & Percentage \\
\hline 1 & Have heard of folic acid & 153 & 76.5 \\
\hline 2 & $\begin{array}{l}\text { Knows that folic acid is } \\
\text { needed for fetal neural devel- } \\
\text { opment }\end{array}$ & 61 & 30.5 \\
\hline 3 & $\begin{array}{l}\text { Knows that folic acid is } \\
\text { needed for the prevention of } \\
\text { anemia }\end{array}$ & 9 & 4.5 \\
\hline \multirow[t]{4}{*}{4} & $\begin{array}{l}\text { Source of information about } \\
\text { folic acid }\end{array}$ & & \\
\hline & Healthcare providers & 145 & 94.7 \\
\hline & Relatives & 5 & 3.3 \\
\hline & Media & 3 & 2 \\
\hline 5 & Knows dose of folic acid & 15 & 7.5 \\
\hline 6 & $\begin{array}{l}\text { Knows about food rich in folic } \\
\text { acid }\end{array}$ & 9 & 4.5 \\
\hline
\end{tabular}

Table 3: Practice of folic acid intake

\begin{tabular}{llcl}
\hline S. no. & Detail & Numbers & Percentage \\
\hline 1 & $\begin{array}{l}\text { Has consumed folic acid } \\
\text { periconceptionally }\end{array}$ & 32 & 16 \\
2 & $\begin{array}{l}\text { Intake of folic acid only after } \\
\text { the diagnosis of pregnancy }\end{array}$ & 150 & 72 \\
3 & $\begin{array}{l}\text { Has consumed folic acid } \\
\text { regularly }\end{array}$ & 164 & 90.1 \\
\hline
\end{tabular}


Table 4: Variables affecting knowledge about folic acid

\begin{tabular}{|c|c|c|c|c|}
\hline S. no. & Detail & $\begin{array}{l}\text { No. of } \\
\text { women }\end{array}$ & $\begin{array}{l}\text { No. of women } \\
\text { heard of folic } \\
\text { acid }\end{array}$ & Percentage \\
\hline \multirow[t]{6}{*}{1} & Education & & & \\
\hline & Uneducated & 3 & 0 & - \\
\hline & Primary & 1 & 0 & - \\
\hline & High school & 47 & 33 & 21.5 \\
\hline & 12th standard & 70 & 55 & 36.9 \\
\hline & $\begin{array}{l}\text { More than 12th } \\
\text { standard }\end{array}$ & 79 & 65 & 42.5 \\
\hline \multirow[t]{5}{*}{2} & Gravidity & & & \\
\hline & 1 & 107 & 81 & 75.5 \\
\hline & 2 & 62 & 47 & 75.5 \\
\hline & 3 & 28 & 22 & 78 \\
\hline & 4 & 3 & 3 & 100 \\
\hline
\end{tabular}

Table 5: Planned conception and periconceptional usage of folic acid

\begin{tabular}{llll}
\hline S.no. & $\begin{array}{l}\text { No. of women with a } \\
\text { planned pregnancy }\end{array}$ & $\begin{array}{l}\text { Periconceptional } \\
\text { usage of folic acid }\end{array}$ & Percentage \\
\hline 1 & 131 & 48 & 36 \\
\hline
\end{tabular}

the major source of information about FA was healthcare providers followed by media and relatives. ${ }^{5,13,21}$

Regarding the overall practice of FA intake among the entire study group, only $16 \%$ of the pregnant women had taken FA periconceptionally, while others took the tablet after confirmation of pregnancy only. Though the results are higher when compared to other studies done in the Indian population, 5,17 it is lower than the practice seen in the western population. ${ }^{21-23}$

Another finding from the study was $65.5 \%$ of women had planned pregnancies which seemed to be lower than that reported by Saxena et al. as $94.25 \%$ and other studies. ${ }^{2,24}$ Among these women who had planned pregnancy, 36\% had taken FA periconceptionally which is found to be higher than observed by Saxena et al. and others. Though this proportion is high when compared to other studies, still the majority of women who had planned to conceive have not taken periconceptional FA. As the age, gravidity and education level increased the number of women who had heard of FA also increased which was also reported in many studies. ${ }^{25-28}$

The practice of intake of FA increased as their educational status increased. Education increases the knowledge about FA which in turn increases FA intake. As the gravidity increased the percentage of women consuming FA decreased ${ }^{5,17}$ (Table 4). This may be due to an increase in the order of pregnancy seen among less-educated women and women from a lower socioeconomic group (Table 5).

\section{Conclusion}

The study has revealed that a good proportion of women have heard of FA, but knowledge about the benefits of FA is low among the study group. Though the proportion of women who had planned pregnancy is high, the practice of periconceptional intake of FA is low which may be due to a lack of knowledge of the benefits of FA. This can be improved by providing health education to the public through awareness campaigns and healthcare providers.
Effectively involving the media can help in reaching out public on a large scale.

\section{References}

1. Rehan M, Mahmood N, Mazhar SB. Knowledge, attitude and practices regarding periconceptional folic acid supplementation in a tertiary care hospital. Ann Pak Inst Med Sci 2015;11(4):172-175.

2. Vitale K, Mujkić A, Todorović G, et al. Is level of knowledge, attitude and use of folic acid among pregnant women in Croatia a call for public health action? Periodicum Biologorum 2009;111(3):329-335.

3. Food and Nutrition Board 1998 Institute of Medicine. Dietary reference intakes for thiamin, riboflavin, niacin, vitamin B6, folate, vitamin B12, pantothenic acid, biotin and choline: a report of the Standing Committee on the Scientific Evaluation of Dietary References Intakes and its Panel on Folate, other B Vitamins and Choline and Subcommittee on Upper Reference Levels for Nutrients. Washington (DC): National Academies Press; 1998. pp. 8-11.

4. Hernandez-Diaz S, Werler MM, Walker AM, et al. Folic antagonist during pregnancy and the risk of birth defects. New Eng J Med 2000;343(22):131-137. DOI: 10.1056/NEJM200011303432204.

5. Deepti K, Anila H, Arup C, et al. Determinants of knowledge regarding folic acid in periconceptional use among pregnant mothers in Southern India. IOSR J Dent Med Sci 2013;4(3):25-29. DOI: 10.9790/0853-0432529.

6. Ray JG, Singh G, Burrows RF. Evidence for suboptimal use of periconceptional folic acid supplements globally. BJOG 2004;111(5):399-408. DOI: 10.1111/j.1471-0528.2004.00115.x.

7. Gupta H, Gupta P. Neural tube defects and folic acid. Indian Pediatr 2004;41:577-586.

8. Hall JG, Sollehhdin F. Genetics of neural tube defects. Ment Retard Dev Disabil 1999;4(4):269-281. DOI: 10.1002/(SICI)10982779(1998)4:4<269::AID-MRDD6>3.0.CO;2-8.

9. Bhide P, Sagoo GS, Moorthie S, et al. Systematic review of birth prevalence of neural tube defects in India. Birth Defects Res A Clin Mol Teratol 2013;97(7):437-443. DOI: 10.1002/bdra.23153.

10. Czeizel AE, Dudás I. Prevention of the first occurrence of neural-tube defects by periconceptional vitamin supplementation. N Engl J Med 1992;327(26):1832-1835. DOI: 10.1056/NEJM199212243272602.

11. Prevention of neural tube defects: results of the medical research council vitamin study. MRC vitamin study research group. Lancet 1991;338(8760):131-137. DOI: 10.1016/0140-6736(91)90133-A.

12. Smithells RW, Seller MJ, Harris R, et al. Further experience of vitamin supplementation for prevention of neural tube defect recurrences. Lancet 1983;1(8332):1027-1031. DOI: 10.1016/S0140-6736(83)92654-5.

13. Keshavarzi F, Ting CM, Yi WM, et al. Periconceptional folic acid usage pattern in Malaysian women. Int J Pharmaceut Clin Res 2016;8(8):1199-1204.

14. WHO Fact Sheet. Congenital Anomalies. Available from: http://www. who.int/mediacentre/factsheets/fs370/en/.

15. A Strategic Approach to Reproductive, Maternal, Newborn, Child and Adolescent Health $(\mathrm{RMNCH}+\mathrm{A})$ in India. Ministry of Health and Family Welfare, Government of India. 2013.

16. Wilson R, Davies G, Desilets V, et al. The use of folic acid for the prevention of neural tube defects and other congenital anomalies. J Obstet Gynaecol Can 2003;25(11):959-973. DOI: 10.1016/S17012163(16)30248-1.

17. Saxena V, Naithani M, Kumari R, et al. Peri-conceptional supplementation of folic acid-knowledge and practices of pregnant women and health providers. J Family Med Prim Care 2016;5(2):387392. DOI: $10.4103 / 2249-4863.192374$.

18. Lumley J, Watson L, Watson M, et al. Periconceptional supplementation with folate and/or multivitamins for preventing neural tube defects. Cochrane Data Base Systema Reviews 2001. CD001056.

19. Ward M, Hutton J, Mc Donnell R, et al. Folic acid supplements to prevent neural tube defects: trends in East of Ireland 1996-2002. Irish Med J 2004;97(9):274-276. 
20. Howell SR, Barnett AG, Underwood MR. The use of pre-conceptional folic acid as an indicator of uptake of a health message amongst white and Bangladeshi women in Tower Hamlets, east London. Fam Pract 2001;18(3):300-303. DOI: 10.1093/fampra/18.3.300.

21. Peake JN, Copp AJ, Shawe J. Knowledge and periconceptional use of folic acid for the prevention of neural tube defects in ethnic communities in the United Kingdom: systematic review and metaanalysis. Birth Defects Res A Clin Mol Teratol 2013;97(7):444-451. DOI: 10.1002/bdra.23154.

22. Eichholzer M, Tönz O, Zimmermann R. Folic acid: a public-health challenge. Lancet 2006;367(9519):1352-1361. DOI: 10.1016/S01406736(06)68582-6.

23. Botto LD, Lisi A, Robert-Gnansia E, et al. International retrospective cohort study of neural tube defects in relation to folic acid recommendations: are the recommendations working? BMJ 2005;330(7491):571-573. DOI: 10.1136/bmj.38336. 664352.82
24. Gjergja R, Stipoljev F, Hafner T, et al. Knowledge and use of folic acid in Croatian pregnant women - a need for health care education initiative. Reprod Toxicol 2006;21(1):16-20. DOI: 10.1016/j. reprotox.2005.07.005.

25. Coll O, Pisa S, Palacio M, et al. Awareness of the use of folic acid to prevent neural tube defects in a Mediterranean area. Eur J Obstet Gynecol Reprod Biol 2004;115(2):173-177. DOI: 10.1016/j. ejogrb.2003.12.009.

26. Morin VI, Mondor M, Wilson RD. Knowledge on periconceptional use of folic acid in women of British Columbia. Fetal DiagnTher 2002;16(2):111-115. DOI: 10.1159/000053892.

27. Canfield MA, Przybyla SM, Case AP, et al. Folic acid awareness and supplementation among Texas women of childbearing age. Prev Med 2006;43(1):27-30. DOI: 10.1016/j.ypmed.2006.01.022.

28. Alozie Arole CN, Puder KS, Reznar M, et al. Folic acid awareness in Michigan, 1996-1999. Obstet Gynecol 2003;102(5 Part 1):1046-1050. DOI: 10.1097/00006250-200311000-00029. 